Original Article

\title{
Osteoprotegerin in Childhood Nephrotic Syndrome: Relation To Glucocorticoids, Parathyroid Hormone and Markers of Bone Metabolism
}

\author{
Gehan Mostafa and Nadia Nagui* \\ Departments of Pediatrics and Clinical Pathology*, Faculty of Medicine, Ain Shams University, \\ Cairo, Egypt
}

\begin{abstract}
Background: A new cytokine system secreted by osteoblast (ostcoprotegerin "OPG" and its ligand "OPGL") that regulates osteoclastogenesis has been recently discovered. OPG is an antiresorptive cytokine as it blocks the biological effects of OPGL which is the final effector of osteoclastogenesis. OPG is downregulated by glucocorticoids $(\mathrm{GC})$. Thus, OPG downregulation may be an important factor contributing to increased bone resorption in steroid-Ireated patients with nephrotic syndrome (NS).

Objective: This study aimed at assessing serum OPG levels in children with NS and to study its relation to the renal disease, steroid therapy, parathyroid hormone (PTH) as well as markers of bone formation (osteocalcin "OC" and alkaline phosphatase "ALP") and resorption (24 hours urinary calcium "Ca").

Methods: Thirty four patients with NS were studied in comparison to 34 healthy children serving as controls. Patients were classificd into 3 groups; group 1 included 8 newly diagnosed patients who were studied before and after a short course (one month) of steroid therapy for the first time. Group 2 included 16 frequent relapsers (FR) and group 3 included 10 infrequent relapsers (IFR). Beside full clinical evaluation, measurements of scrum OPG (ELISA), OC (radioimmunoassay), PTH (immunoradiometric assay), ALP and 24 hours urinary $\mathrm{Ca}$ and proteins were performed.

Results: Patients with NS, whether compiled in one group or classified into newly diagnosed patients prior to steroid therapy, FR and IFR, had a significantly lower OPG and parameters of bone formation (OC and ALP) and a significantly higher 24 hours urinary Ca than controls. A short course of GC therapy for one month received by the newly diagnosed patients with NS resulted in significant decrease of serum OPG, OC and ALP and a significant increase of 24 hours urinary $\mathrm{Ca}$. In contrast, serum PTH was not significantly affected by this therapy. Patients who were FR had a significantly higher cumulative steroid dose than those who were IFR $(p<0.0001)$. The former group had a significantly lower serum OPG, OC and ALP and a significantly higher 24 hours uninary $\mathrm{Ca}$ and serum PTH than the latter group. Serum OPG and OC were decreased in $85.3 \%$ and $76 \%$, respectively of patients with NS. On the other hand, serum PTH and 24 hours urinary Ca were elevated in $61.8 \%$ and $79.4 \%$ of these patients, respectively. OPG had a significant negative correlation with markers of disease activity and severity (ESR, serum cholesterol, 24 hours urinary protein and cumulative steroid dose), PTH and 24 hours urinary $\mathrm{Ca}$. On the other hand, OPG had a significant positive correlation with OC and ALP. Conclusions: Osteoporosis in NS could be attributed to both cnhancement of bone resorption and suppression of bone formation. Low serum OPG expression, which could be attributed to the renal disease itself and steroid therapy, may be an important factor contributing to bone resorption in NS. Thus, OPG administration may be considered as a new hopeful therapeutic modality for osteoporosis in NS, especially in patients who are frequent relapsers and with high cumulative steroid dose. Further studies regarding the protective effects of OPG adrninistration against bone loss in NS are warranted.
\end{abstract}

\section{INTRODUCTION}

Children with nephrotic syndrome (NS) may be at risk for metabolic bone disease because of biochemical derangements caused by the renal disease as well as steroid therapy ${ }^{(1)}$. 
Osteoporosis is a well. known serious side effect of long-term treatment with glucocorticoids (GC). However, the precise mechanisin of this disorder is unclear ${ }^{(2)}$. Pharmacologic doses of GC are associated with decreased gastrointestinal calcium (Ca) absorption and increased urinary $\mathrm{Ca}$ excretion resulting in a negative calcium balance. Furthermore, GC stimulate bone resorption directly by enhancing osteoclast activity and indirectly via increasing parathyroid hormone (PTH) production. In addition, GC directly inhibit bone formation by suppression of type 1 collagen synthesis and by decreasing osteoblast differentiation with a resultant decrease of its products including osteocalcin (OC). Osteocalcin is the major non-collagenous bone protein, which is an ideal marker, with almost complete bone specificity, used for specific measurement of bone formation. Moreover, a drop in OC serum level may be an early marker for steroid-induced osteoporosis. Sometimes, chronic GC administration leads to aseptic or avascular bone necrosis, a painful and disabling complication resulting from GC induced osteocyte apoptosis ${ }^{(3)}$.

The abnormal bone histology in patients with NS, which is mostly osteomalacia and increased bone resorption, can not be readily explained by the prevalent concentrations of PTH and vitamin D metabolites $^{(4)}$. In recent years, a new cytokine system secreted by osteoblasts that regulates osteoclastogenesis has been discovered which is osteoprotegerin ("OPG", latin: OS, bone; Protegere, to protect), a member of the tumour necrosis factor receptor superfamily, and osteoprotegerin-ligand "OPGL" or receptor activator of nuclear
factor-Kappa B ligand "RANKL" ${ }^{(5,6)}$. OPGL is the final effector of osteoclastogenesis that promotes osteoclast formation (osteoclast differentiation factor) and activation, and inhibits osteoclast apoptosis ${ }^{(7)}$. Osteoprotegerin blocks the biological effects of OPGL ${ }^{(5)}$. Thus, alterations in OPG/OPGL ratio could form the basis of some metabolic bone diseases like osteoporosis ${ }^{(5,6)}$.

Several studies have shown that PTH acts by enhancing the production of OPGL and by inhibiting the synthesis of $O P G^{(5)}$. Also, it has been proposed that glucocorticoid administration results in suppression of serum OPG and overexpression of OPGL. This may be an important factor participating in glucocorticoid-induced osteoporosis $^{(2)}$.

Exogenous administration of OPG has been shown to increase bone mass and prevent bone loss ${ }^{(8)}$. Thus, OPG may represent a potential therapeutic target in pathologic processes that are characterized by excessive bone resorption ${ }^{(5)}$.

\section{AIM OF THE WORK}

The aim of this study was to assess serum osteoprotegerin (osteoclastogenic inhibitory factor) in children with NS and to study its relation to the renal disease (activity and severity), steroid therapy (duration and cumulative dose), PTH as well as markers of bone metabolism (osteocalcin and alkaline phosphatase as markers of bone formation and 24 hours urinary $\mathrm{Ca}$ as a marker of bone resorption).

\section{METHODS}

\section{Study population}

This case-control follow-up study was 
conducted over a period of 9 months from the first of November 2004 to the end of July 2005. It included 34 children ( 23 males and 11 females) with nephrotic syndrome recruited from the Pediatric Nephrology Unit, Children's Hospital, Ain Shams University. The diagnosis of nephrotic syndrome was established according to the criteria of the International Study of Kidney Disease in Children $^{(9)}$. Their ages ranged from 3 to 10 years (mean \pm SD: $6.62+1.9$ years). An informed consent was obtained from their parents or caregivers before enrollment in the study.

Clinical evaluation of the patients was done based on clinical history from the caregivers, reviewing follow-up sheets and clinical examination. Special emphasis was layed on; disease duration, frequency of relapses, manifestations suggesting metabolic bone disease (as bony pains, fractures and deformity) and GC therapy (duration, response, side effects and the cumulative dose during the whole disease duration used per square meter body surface area obtained from the patients' records).

Patients were classified into 3 groups:

Group I: Included 8 patients ( 5 males and 3 females) with a recent diagnosis of NS. They were studied before and after a short course of steroid therapy for the first time $\left(60 \mathrm{mg} / \mathrm{m}^{2}\right.$ surface area for one month). Their ages ranged from 3 to 10 years (mean $\pm \mathrm{SD}: 6.25 \pm 2.5$ years).

Group II: Included 16 patients $(11$ males and 5 females) who were frequent relapsers (FR), i.e. with 2 or more relapses within 6 months of the initial response or 4 or more relapses within any 12 months period ${ }^{(10)}$. All patients were steroid dependent i.e. with 2 consecutive relapses occurring during or within 14 days of steroid cessation ${ }^{(10)}$. Their ages ranged from 4 to 10 years (mean $+\mathrm{SD}: 6.56+1.8$ years). All patients were studied during relapse (oedemat, urinary protein excretion $>40 \mathrm{mg} / \mathrm{hr} / \mathrm{m}^{2}$ or Albustix $=++$ or more for 3 consecutive days $)^{(10)}$

Group III: Included 10 patients (7 males and 3 females) who were infrequent relapsers (IFR) and steroid responsive i.e. remission achieved with steroid therapy alone $^{(10)}$. Their ages ranged from 4 to 10 years (mean $\pm \mathrm{SD}: 7 \pm 1.8$ years). All patients were studied during relapse.

Patients with NS were excluded from the study if they had impaired renal function (creatinine clearance $<80 \mathrm{ml} / \mathrm{min}$ ), secondary NS or if they were recipients of cytotoxic therapy or oral vitamin D (factors that may affect bone metabolism).

Patients were studied in comparison to 34 (23 males and 11 females) age- and sexmatched healthy children, with no clinical evidence of any disease or condition which may affect bone metabolism, serving as controls. Their ages ranged from 3 to 10 years (mean $\pm \mathrm{SD}$ : $6.4 \pm 2$ years).

\section{Study measurements}

\section{Sample collection}

Six milliliters of venous blood were collected. Four milliliters were transferred into a clean dry tube and left to clot. An aliquot of prompt separated serum was used for direct assay of urea, creatinine, calcium (Ca), phosphorus (P), alkaline phosphatase (ALP), cholesterol and albumin. Part of serum was stored at $-20^{\circ} \mathrm{C}$ until assay of parathyroid hormone, osteocalcin and osteoprotegerin. The other two milliliters 
were collected on sodium citrate for erythrocyte sedimentation rate (ESR) assay by Westergren method.

A sample of 24 hours urine was taken for determination of urinary creatinine, total protein and calcium. The urine was collected in sterile containers with no preservatives. It was stored at $2-8^{\circ} \mathrm{C}$ till the time of the assay.

Routine assessment of serum Ca, P, ALP, creatinine, cholesterol and proteins was carried out on Synchron CX7 autoanalyzer (Beckman instruments, Brea, California, USA)

Determination of urinary creatinine, protein and calcium was also carried out using the Synchron $\mathrm{Cx} 7$ autoanalyzer. Correction for the total volume was done to obtain the actual value in 24 hours urine. The corrected creatinine clearance, according to the surface area, for every patient was then calculated.

Estimation of serum intact parathyroid hormone (PTH) and serum intact osteocalcin $(O C)$ was carried out with electrochemiluminescence immunoassays (ECLIA) on the automated analyzer Elecsys 2010 (Roche Diagnostics, Mannheim, Germany). The Elecsys intact-PTH ECLIA uses a biotinylated monoclonal antibody, which reacts with amino acids 26-32, and a capture ruthenium-complexed monoclonal antibody, which reacts with amino acids 55-64. The Elecsys N-terminal midfragment $\mathrm{OC}$ is specific for intact OC (amino acids 1-49) and the main $\mathrm{N}$-terminal fragment (amino acids 1-43). Both intact osteocalcin (amino acids 1-49) and the large N-Mid fragment (amino acids 1-43) occur in blood. Intact osteocalcin is unstable due to protease cleavage between amino acids 43 and 44 . The N-Mid-fragment resulting from cleavage is considerably more stable. The Elecsys N-MID osteocalcin assay uses two monoclonal antibodies specifically directed against epitopes on the N-Mid fragment (biotinylated monoclonal antibody) and the $\mathrm{N}$-terminal fragment (rutheniumcomplexed antibody). The test is nondependent on the unstable C-terminal fragment (amino acids 43-49) of the osteocalcin molecule and thus ensues constant measurement results under routine conditions in the laboratory ${ }^{(11)}$.

For the PTH and OC assay, the sample was added to a cuvette followed by addition of the two specific antibodies and the streptavidin-coated magnetic particles. The reaction mixture was incubated for 30 minutes at $37^{\circ} \mathrm{C}$. Because of the high affinity interaction between biotin labeled antibody and streptavidin, the sandwich complex was captured onto the streptavidin magnetic particles. The captured complex bound to the magnetic particles was then washed by the system to remove unbound components. The cuvette wells containing the washed magnetic particles were transported into the system luminometer where the chemiluminescence reaction took place. The light was quantitated by the luminometer and expressed as RLU. The amount of bound-labeled antibody was directly proportional to the concentration of intact PTH in the sample ${ }^{(12)}$

Assessment of serum osteoprotegerin $(O P G)$ was done by using enzyme linked immunosorbent assay (ELISA) method (Biovendor Laboratory Medicine, Inc., Palackeho, Czech Republic). Assay procedure: diluted standards, quality controls and serum samples were added to microplate wells coated with capture 
monoclonal antiosteoprotegerin antibody After incubation and washing steps, biotin labeled polyclonal antihuman osteoprotegerin antibody solution was added for a further incubation step. Following a final washing step, hydrogen peroxide tetramethylbenzidine was incubated into the wells resulting in a coloured product. After the addition of oxidic stop solution, the colour was measured at $450 \mathrm{~nm}$. The absorbance and colour intensity were considered proportional to the concentration of OPG in the sample. A standard curve was constructed and the concentration of OPG in the samples was determined ${ }^{(13)}$.

\section{Statistical Analysis}

The results were analyzed by commercially available software package (StatView, Abacus concepts, Inc., Berkeley, CA, USA). The data were presented as mean and standard deviation, in addition to median and interquartile range (IQR) Mann-Whitney (z) test was used for comparison between two groups as data distribution was non-parametric. Wilcoxon signed Ranks test was used for comparison between newly diagnosed patients with NS before and after GC therapy. Spearman correlation coefficient " $r$ " was used to determine the relationship between different variables. For all tests, a probability (p) of less than 0.05 was considered significant. As data distribution was non-parametric, patients were considered to have low serum OPG and OC if their levels were below the $5^{\text {th }}$ percentile of the control values $(0.8 \mathrm{pg} /$ $\mathrm{ml}$ for $\mathrm{OPG}$ and $10.7 \mathrm{ng} / \mathrm{mL}$ for $\mathrm{OC}$ ). In addition, patients were considered to have elevated serum PTH and 24 hours urinary $\mathrm{Ca}$ if their levels were above the $95^{\text {th }}$ percentile of the control values $(44.35 \mathrm{pg} / \mathrm{ml}$ for PTH and $133.5 \mathrm{mg} / 24$ hours for urinary $\mathrm{Ca})$.

\section{RESULTS}

Serum OPG, PTH and laboratory markers of bone metabolism in steroidtreated patients with NS and controls:

Children with NS, whether compiled in one group or classified into FR and IFR, had significantly lower serum OPG, OC and ALP and significantly higher 24 hours urinary $\mathrm{Ca}$ than healthy controls. Serum PTH was significantly higher in patients who were FR than controls, but there was an insignificant difference between patients who were IFR and healthy controls (Tables $1,2 \& 3$ ). On the other hand, there was no significant difference in serum levels of $\mathrm{Ca}$ and $P$ of the patients with NS and that of the healt hy controls $(p>0.05)$

Serum OPG, PTH and laboratory markers of bone metabolism in relation to renal disease itself (i.e. without the effect of GC):

Newly diagnosed patients with NS, prior to GC therapy, had significantly lower serum OPG, OC and ALP and significantly higher 24 hours urinary $\mathrm{Ca}$ than healthy controls (Tables 1, 2 \& 3). In contrast, there was an insignificant difference between the former and the latter groups in serum levels of $\mathrm{Ca}, \mathrm{P}$ and PTH $(\mathrm{p}>0.05)$.

Serum OPG, PTH and laboratory markers of bone metabolism in relation to a short course of GC therapy:

A short course of steroid therapy (60 $\mathrm{mg} / \mathrm{m}^{2}$ for one month) for the first time received by the newly diagnosed patients with NS resulted in a significant decrease of 
serum OPG, OC and ALP and a significant increase of 24 hours urinary $\mathrm{Ca}$ (Tables 1,2 \& 3). In contrast, the one month GC therapy did not seem to significantly affect the serum levels of any of $\mathrm{Ca}, \mathrm{P}$ and PTH ( $p>$ $0.05)$

Serum OPG, PTH and laboratory markers of bone metabolism in relation to frequency of relapses and cumulative steroid dose:

Patients with NS who were FR had received a significantly higher cumulative steroid dose than IFR [median (IQR): 45350 (7250) versus $15200(7375) \mathrm{mg} / \mathrm{m}^{2}$ respectively, $z=4.2, p<0.0001]$. The former group had significantly lower serum OPG, $O C$ and ALP and significantly higher serum PTH and 24 hours urinary $\mathrm{Ca}$ than the latter group (Tables 1, $2 \& 3$ ). In contrast, there were insignificant differences between both groups in serum levels of $\mathrm{Ca}$ and $\mathrm{P}(\mathrm{p}>$ 0.05 )

Percentage of patients with low serum OPG and OC and high serum PTH and 24 hours urinary $\mathrm{Ca}$ :

Eighty five percent and $76.5 \%$ of patients with NS had low serum OPG and OC, respectively. On the other hand, $79.4 \%$ and $61.8 \%$ of them had increased 24 hours urinary $\mathrm{Ca}$ and serum PTH, respectively. Interestingly all FR patients had low serum OPG and OC. In contrast, $50 \%$ and $20 \%$ only of IFR patients had low serum $O P G$ and $O C$, respectively. Both serum PTH and 24 hours urinary $\mathrm{Ca}$ were elevated in $87.5 \%$ of $\mathrm{FR}$ patients while they were elevated in 50\% and $40 \%$, respectively of IFR patients. Newly diagnosed patients with NS had low serum OPG and OC in $37.5 \%$ and $62.5 \%$, respectively and elevated 24 hours urinary $\mathrm{Ca}$ and serum PTH in 50\%. After one month of GC, all these patients had low serum OPG and $\mathrm{OC}$ and increased 24 hours urinary $\mathrm{Ca}$ excretion, while $37.5 \%$ only had elevated serum PTH.

Correlation analysis:

Correlation between $O P G$ and indices of both disease severity (cumulative steroid dose and 24-hours urinary protein) and activity (ESR, serum cholesterol and albumin):

OPG had a significant negative correlation with cumulative steroid dose (Fig. 1A), 24 hours urinary protein (Fig. 1B), ESR (Fig. 2A) and serum cholesterol (Fig. 2B). On the other hand, OPG had a significant positive correlation with serum albumin (Fig. 2C)

Correlation between OPG and PTH:

OPG had a significant negative correlation with PTH (Fig. 2D).

Correlation between $O P G$ and laboratory markers of bone metabolism:

OPG had a significant positive correlation with laboratory markers of bone formation (OC and ALP $\mathrm{r}=0.96$ and 0.9 respectively, $p<0.0001)$. On the other hand, OPG had a significant negative correlation with 24 hours urinary $\mathrm{Ca}$, the studied laboratory marker of bone resorption, $(r=-0.92, p<0.0001)$.

OPG did not correlate significantly with either the age of the patients or the duration of illness $(p>0.05)$ 
Table 1: Comparison between different studied groups in serum levels of osteoprotegerin.

\begin{tabular}{|c|c|c|c|}
\hline & \multicolumn{3}{|c|}{ Serum osteoprotegerin $(\mathrm{pg} / \mathrm{mL})$} \\
\hline & Mean \pm SD & Median (IQR) & $\begin{array}{l}z \\
\text { p }\end{array}$ \\
\hline $\begin{array}{l}\text { All patients with NS }(n=34) \\
\quad \text { vs } \\
\text { Healthy controls }(n=34)\end{array}$ & $\begin{array}{c}0.6 \pm 0.35 \\
\text { vs } \\
1.39 \pm 0.28\end{array}$ & $\begin{array}{l}0.65(0.7) \\
\text { vs } \\
1.4(0.3)\end{array}$ & $\begin{array}{c}6.3 \\
<\mathbf{0 . 0 0 0 1 *}\end{array}$ \\
\hline $\begin{array}{l}\text { Newly diagnosed patients with } \\
\text { NS }(\mathrm{n}=8) \\
\quad \text { vs } \\
\text { Healthy controls }\end{array}$ & $\begin{array}{l}0.93 \pm 0.2 \\
v s \\
1.39 \pm 0.28\end{array}$ & $\begin{array}{c}0.95(0.38) \\
\text { vs } \\
1.4(0.3)\end{array}$ & $\begin{array}{c}3.4 \\
<\mathbf{0 . 0 0 0 1 ^ { \mathrm { nn } }}\end{array}$ \\
\hline $\begin{array}{l}\text { FR patients with NS }(n=16) \\
\quad \text { vs } \\
\text { Healthy controls }\end{array}$ & $\begin{array}{l}0.27 \pm 0.15 \\
\text { vs } \\
1.39 \pm 0.28\end{array}$ & $\begin{array}{l}0.2(0.1) \\
\text { vs } \\
1.4(0.3)\end{array}$ & $\begin{array}{c}5.6 \\
<0.0001^{*}\end{array}$ \\
\hline $\begin{array}{l}\text { IFR patients with NS }(n=10) \\
\quad \text { vs } \\
\text { Healthy controls }\end{array}$ & $\begin{array}{l}0.86 \pm 0.13 \\
\text { vs } \\
1.39 \pm 0.28\end{array}$ & $\begin{array}{l}0.85(0.15) \\
\text { vs } \\
1.4(0.3)\end{array}$ & $<\stackrel{4}{4}^{4}$ \\
\hline $\begin{array}{l}\text { FR patients with NS } \\
\quad \text { vs } \\
\text { IFR patients with NS }\end{array}$ & $\begin{array}{l}0.27 \pm 0.15 \\
\text { vs } \\
0.86 \pm 0.13\end{array}$ & $\begin{array}{c}0.2(0.1) \\
\mathrm{vs} \\
0.85(0.15)\end{array}$ & $\begin{array}{c}4.26 \\
<\mathbf{0 . 0 0 0 1}\end{array}$ \\
\hline $\begin{array}{l}\text { Newly diagnosed patients with } \\
\text { NS before and after a short course } \\
\text { of steroid therapy }\end{array}$ & $\begin{array}{l}0.93 \pm 0.2 \\
\quad \text { vs } \\
0.4 \pm 0.15\end{array}$ & $\begin{array}{l}0.95(0.38) \\
\text { vs } \\
0.4(0.18)\end{array}$ & $\begin{array}{c}2.53 \\
<0.05^{*}\end{array}$ \\
\hline
\end{tabular}

NS: nephrotic syndrome, FR: frequent relapsers, IFR: infrequent relapsers, $\mathrm{p}<0.05^{*}$ : significant, $\mathrm{p}<0.000 \mathrm{I}^{* *}$ highly significant 
Table 2: Comparison between different studied groups in serum levels of laboratory markers of bone formation (OC and ALP).

\begin{tabular}{|c|c|c|c|c|c|c|}
\hline & \multicolumn{3}{|c|}{ Serum alkaline phosphatase (IU/L) } & \multicolumn{3}{|c|}{ Serum osteocalcin $(\mathrm{ng} / \mathrm{mL})$} \\
\hline & $\operatorname{Mean} \pm$ SD & $\begin{array}{l}\text { Median } \\
\text { (IQR) }\end{array}$ & $\begin{array}{l}\text { z } \\
\mathbf{p}\end{array}$ & Mean \pm SD & $\begin{array}{l}\text { Median } \\
\text { (IQR) }\end{array}$ & $\begin{array}{l}\mathbf{z} \\
\mathbf{p}\end{array}$ \\
\hline $\begin{array}{l}\text { All patients } \\
\text { with } N S(n=34) \\
\quad \text { vs } \\
\text { Healthy controls } \\
(\mathrm{n}=34)\end{array}$ & $\begin{array}{c}97.4 \pm 34.5 \\
\text { vs } \\
155.4 \pm 30\end{array}$ & $\begin{array}{c}92(65.8) \\
\text { vs } \\
160(33.8)\end{array}$ & $\begin{array}{c}5.7 \\
<0.0001^{* *}\end{array}$ & $\begin{array}{c}7.3 \pm 4.16 \\
\text { vs } \\
13.1 \pm 1.66\end{array}$ & $\begin{array}{c}6.8(8) \\
\text { vs } \\
13.35(3)\end{array}$ & $\begin{array}{c}5.4 \\
<0.0001^{\prime \prime}\end{array}$ \\
\hline $\begin{array}{l}\text { Newly diag- } \\
\text { nosed patients } \\
\text { with NS }(n=8) \\
\text { vs } \\
\text { Healthy controls }\end{array}$ & $\begin{array}{c}106 \pm 16 \\
\text { vs } \\
155.4 \pm 30\end{array}$ & $\begin{array}{c}106.5(28) \\
\text { vs } \\
160(33.8)\end{array}$ & $\begin{array}{c}3.5 \\
<0.0001^{\text {*t }}\end{array}$ & $\begin{array}{c}9.46 \pm 2.18 \\
\text { vs } \\
13.1 \pm 1.66\end{array}$ & $\begin{array}{c}9.65(3.85) \\
\text { vs } \\
13.35(3)\end{array}$ & $\begin{array}{c}3.6 \\
<0.0001^{* *}\end{array}$ \\
\hline $\begin{array}{l}\text { FR patients with } \\
\text { NS }(n=16) \\
\text { vs } \\
\text { Healthy controls }\end{array}$ & $\begin{array}{c}66.8 \pm 13.9 \\
\text { vs } \\
155.4 \pm 30\end{array}$ & $\begin{array}{c}63.5(22) \\
v s \\
160(33.8)\end{array}$ & $\begin{array}{c}5.6 \\
<\mathbf{0 . 0 0 0 1}\end{array}$ & $\begin{array}{c}3.45 \pm 1.5 \\
v s \\
13.1 \pm 1.66\end{array}$ & $\begin{array}{c}3.15(1.4) \\
\text { vs } \\
13.35(3)\end{array}$ & $\begin{array}{c}5.6 \\
<0.0001^{* *}\end{array}$ \\
\hline $\begin{array}{l}\text { IFR patients } \\
\text { with NS }(\mathrm{n}=10) \\
\quad \text { vs } \\
\text { Healthy controls }\end{array}$ & $\begin{array}{c}139.6 \pm 11.8 \\
\text { vs } \\
155.4 \pm 30\end{array}$ & $\begin{array}{c}139.5(13.8) \\
v s \\
160(33.8)\end{array}$ & $\begin{aligned} & 2.5 \\
< & \mathbf{0 . 0 5}\end{aligned}$ & $\begin{array}{c}11.8 \pm 1.6 \\
v s \\
13.1 \pm 1.66\end{array}$ & $\begin{array}{c}11.3(1.8) \\
v s \\
13.35(3)\end{array}$ & $\begin{array}{c}2 \\
<0.05^{*}\end{array}$ \\
\hline $\begin{array}{l}\text { FR patients with } \\
\text { NS } \\
\text { vs } \\
\text { IFR patients with } \\
\text { NS }\end{array}$ & $\begin{array}{c}66.8 \pm 13.9 \\
\text { vs } \\
139.6 \pm 11.8\end{array}$ & $\begin{array}{c}63.5(22) \\
\text { vs } \\
139.5(13.8)\end{array}$ & $\begin{array}{c}4.2 \\
<\mathbf{0 . 0 0 1}\end{array}$ & $\begin{array}{c}3.45 \pm 1.5 \\
\mathrm{vs} \\
11.8 \pm 1.6\end{array}$ & $\begin{array}{c}3.15(1.4) \\
\text { vs } \\
11.3(1.8)\end{array}$ & $\begin{array}{c}4.2 \\
<0.0001^{* * *}\end{array}$ \\
\hline $\begin{array}{l}\text { Newly diag- } \\
\text { nosed patients } \\
\text { with NS before } \\
\text { and after a short } \\
\text { course of steroid } \\
\text { therapy }\end{array}$ & $\begin{array}{c}106 \pm 16 \\
\text { vs } \\
96.9 \pm 12.9\end{array}$ & $\begin{array}{c}106.5(28) \\
\text { vs } \\
96(21)\end{array}$ & $\begin{array}{r}2.4 \\
<0.05^{*}\end{array}$ & $\begin{array}{c}9.46 \pm 2.18 \\
\text { vs } \\
4.9 \pm 1.85\end{array}$ & $\begin{array}{c}9.65(3.85) \\
\text { vs } \\
5(1)\end{array}$ & $\begin{array}{r}2.5 \\
<\mathbf{0 . 0 5}\end{array}$ \\
\hline
\end{tabular}

NS: nephrotic syndrome, FR: frequent relapsers, [FR: infrequent relapsers, $\mathrm{p}<0.05^{*}$ : significant, $\mathrm{p}<0.01,0.001$, $0.0001^{* *}$ : highly significant. 
Table 3: Comparison between different studied groups in levels of 24 hours urinary Ca (a marker of bone resorption) and serum PTH.

\begin{tabular}{|c|c|c|c|c|c|c|}
\hline & \multicolumn{3}{|c|}{ Serum parathyroid hormone $(\mathrm{pg} / \mathrm{ml})$} & \multicolumn{3}{|c|}{24 hours urinary $\mathrm{Ca}$ ( $\mathrm{mg} / 24$ hours) } \\
\hline & Mean $\pm S D$ & $\begin{array}{l}\text { Median } \\
\text { (IQR) }\end{array}$ & $\begin{array}{l}y \\
p\end{array}$ & Mean \pm SD & $\begin{array}{l}\text { Median } \\
\text { (IQR) }\end{array}$ & $\begin{array}{l}\mathbf{z} \\
\mathbf{p}\end{array}$ \\
\hline $\begin{array}{l}\text { All patients with } \\
\text { NS }(n=34) \\
\quad \text { vs } \\
\text { Healthy controls } \\
(n=34)\end{array}$ & $\begin{array}{c}67.6 \pm 38.5 \\
\text { vs } \\
32.6 \pm 8.1\end{array}$ & $\begin{array}{c}55.5(78) \\
v s \\
32.5(14)\end{array}$ & $\begin{array}{c}3.93 \\
<0.001^{\text {"* }}\end{array}$ & $\begin{array}{c}209.7 \pm 113.6 \\
\text { vs } \\
91.8 \pm 18.6\end{array}$ & $\begin{array}{c}162.5(182) \\
\text { vs } \\
89(29.5)\end{array}$ & $\begin{array}{c}5.38 \\
<0.0001^{\text {* }}\end{array}$ \\
\hline $\begin{array}{l}\text { Newly diag- } \\
\text { nosed patients } \\
\text { with NS }(\mathrm{n}=8) \\
\quad \text { vs } \\
\text { Healthy controls }\end{array}$ & $\begin{array}{c}38.5 \pm 15.4 \\
v s \\
32.6 \pm 8.1\end{array}$ & $\begin{array}{c}36.5(28.5) \\
\text { vs } \\
32.5(14)\end{array}$ & $\begin{array}{c}0.83 \\
>0.05\end{array}$ & $\begin{array}{c}130.6 \pm 34.9 \\
v s \\
91.8 \pm 18.6\end{array}$ & $\begin{array}{c}130(63.8) \\
\text { vs } \\
89(29.5)\end{array}$ & $\begin{aligned} & 2.97 \\
< & \mathbf{0 . 0 1}\end{aligned}$ \\
\hline $\begin{array}{l}\text { FR patients with } \\
\text { NS }(n=16) \\
\text { vs } \\
\text { Healthy controls }\end{array}$ & $\begin{array}{c}99.3 \pm 32.5 \\
v s \\
32.6 \pm 8.1\end{array}$ & $\begin{array}{c}110(29.5) \\
\text { vs } \\
32.5(14)\end{array}$ & $\begin{array}{c}4.8 \\
<0.0001^{\text {** }}\end{array}$ & $\begin{array}{c}302.8 \pm 97.7 \\
\text { vs } \\
91.8 \pm 18.6\end{array}$ & $\begin{array}{c}310(115) \\
\text { vs } \\
89(29.5)\end{array}$ & $\begin{array}{c}5.3 \\
<0.0001\end{array}$ \\
\hline $\begin{array}{l}\text { IFR patients } \\
\text { with NS }(\mathrm{n}=10) \\
\text { vs } \\
\text { Healthy controls }\end{array}$ & $\begin{array}{c}40.3 \pm 11.3 \\
v s \\
32.6 \pm 8.1\end{array}$ & $\begin{array}{c}38.5(18.5) \\
\text { vs } \\
32.5(14)\end{array}$ & $\begin{array}{c}1.83 \\
>0.05\end{array}$ & $\begin{array}{c}124 \pm 36.3 \\
\text { vs } \\
91.8 \pm 18.6\end{array}$ & $\begin{array}{c}132.5(42.5) \\
v s \\
89(29.5)\end{array}$ & $\begin{array}{c}2.6 \\
<0.01\end{array}$ \\
\hline $\begin{array}{l}\text { FR patients with } \\
\text { NS } \\
\quad \text { vS } \\
\text { IFR patients with } \\
\text { NS }\end{array}$ & $\begin{array}{c}99.3 \pm 32.5 \\
v s \\
40.3 \pm 11.3\end{array}$ & $\begin{array}{c}110(29.5) \\
v \mathrm{~s} \\
38.5(18.5)\end{array}$ & $\begin{array}{c}3.4 \\
<0.0001^{* *}\end{array}$ & $\begin{array}{c}302.8 \pm 97.7 \\
\text { vs } \\
124 \pm 36.3\end{array}$ & $\begin{array}{c}310(115) \\
\text { vs } \\
132.5(42.5)\end{array}$ & $\begin{array}{c}3.4 \\
<0.0001^{\text {** }}\end{array}$ \\
\hline $\begin{array}{l}\text { Newly diag- } \\
\text { nosed patients } \\
\text { with NS before } \\
\text { and after a short- } \\
\text { course of steroid } \\
\text { therapy }\end{array}$ & $\begin{array}{c}38.5 \pm 15.4 \\
\text { vs } \\
36.9 \pm 14.3\end{array}$ & $\begin{array}{c}36.5(28.5) \\
\text { vs } \\
35.5(26)\end{array}$ & $\begin{array}{c}1.72 \\
>0.05\end{array}$ & $\begin{array}{c}130.6 \pm 34.9 \\
\text { vs } \\
302.5 \pm 72.7\end{array}$ & $\begin{array}{c}130(63.8) \\
\text { vs } \\
315(117.5)\end{array}$ & $\begin{array}{c}2.52 \\
<0.05^{\star}\end{array}$ \\
\hline
\end{tabular}

NS: nephrotic syndrome, FR: frequent relapsers, IFR: infrequent relapsers, $p>0.05$ : insignificant, $p<0.05^{*}$ : significant, $\mathrm{p}<0.01,0.001,0.0001^{* *}$ : highly significant 


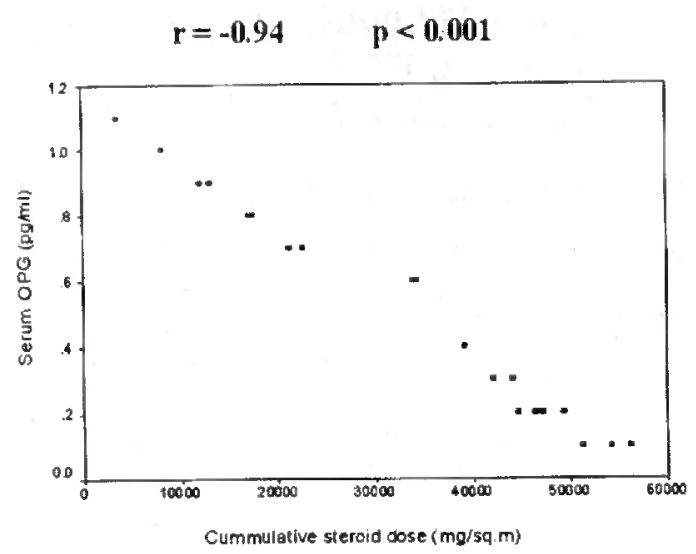

A

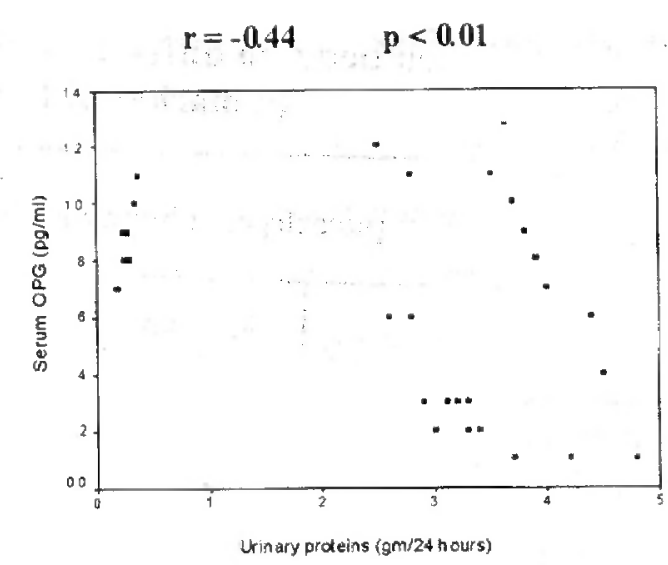

B

Fig. 1: Correlation between OPG and both cumulative steroid dose (Fig. 1A) and 24 hours urinary proteins (Fig. 1B).

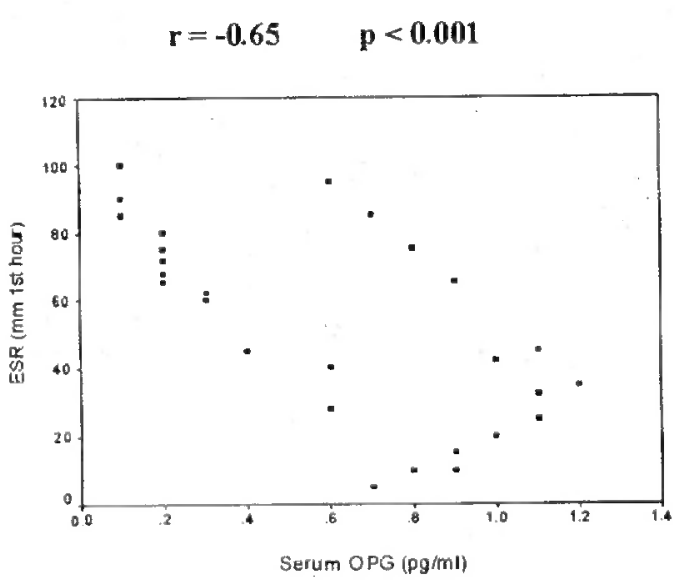

A

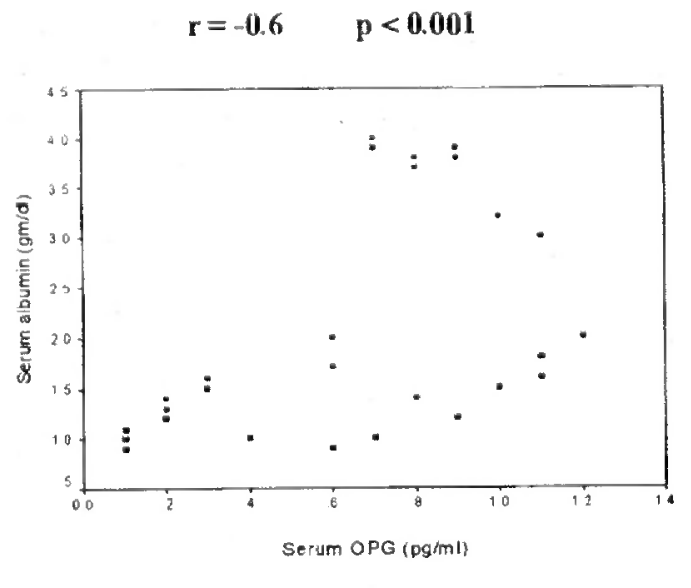

C

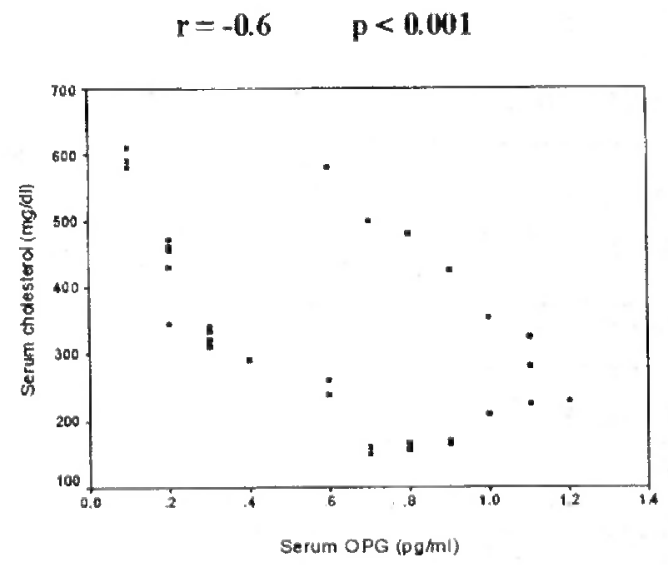

B

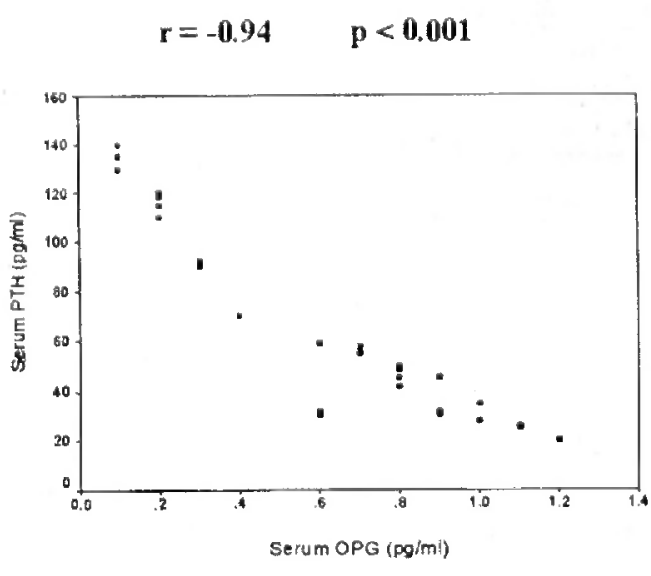

D

Fig. 2: Correlation between OPG and both laboratory markers of nephrotic syndrome activity "ESR, serum cholesterol and albumin" (Fig. 2A, B \& C) and PTH (Fig. 2D). 


\section{DISCUSSION}

The pathogenesis of bone loss in NS is not fully understood. It could be attributed to the renal disease itself as well as steroid therapy ${ }^{(1)}$. Osteoprotegerin, a member of the TNF-receptor family secreted by osteoblasts, is an antiresorptive cytokine ${ }^{(5,6)}$ that is downregulated by GC. It binds with a strong affinity to its ligand (OPGL or RANKL) preventing it from binding to its receptor $\mathrm{RANK}^{(14)}$. Thus, OPG is a decoy receptor for RANK blocking the osteoclastogenesis induced by RANKL ${ }^{(6)}$. It has been shown that exogenous OPG administration prevents bone loss and increases bone mass ${ }^{(8)}$.

In the present study, patients with NS, whether compiled in one group or classified into FR or IFR, had significantly lower serum OPG than healthy controls. To our knowledge, this is the first study assessing serum OPG levels in children with NS.

Our study revealed that GC therapy may be an important factor contributing to low serum OPG expression in NS. This was evidenced by the significant reduction of serum OPG in patients who were FR (with higher cumulative steroid dose) than those who were IFR (with lower cumulative steroid dose). In addition, OPG had a significant negative correlation with cumulative steroid dose meaning that the higher the cumulative dose of $\mathrm{GC}$ received by those patients, the lower the serum OPG expression. It has been proposed that GC supports osteoblastic bone resorption by increasing the levels of RANKL and reducing $O P G$ expression by direct suppression of osteoblast differentiation. Thus, GC enhances the ratio of RANKL to
OPG resulting in promotion of osteoclastogenesis and bone loss $\mathrm{s}^{(2,15)}$

Another important reason behind $\mathrm{OPG}$ downregulation in our patients with NS may be the renal disease itself. This was evidenced by the significant decrease of OPG in newly diagnosed patients with NS, prior to GC therapy, compared to healthy controls. Another important clue for the possible role of the renal disease in downregulation of OPG is our finding of a significant negative correlation between OPG and markers of disease activity (high ESR and serum cholesterol and low serum albumin) and severity ( 24 hours urinary proteins). We could not trace similar data in the literature to compare our results. Thus, studies on the exact mechanism by which the inflammatory process of NS may result in OPG downregulation are warranted.

In our series, OPG had a significant positive correlation with the studied marker of bone resorption ( 24 hours urinary $\mathrm{Ca}$ ) meaning that the lower were the serum OPG levels, the higher the degree of bone resorption resulting in more urinary $\mathrm{Ca}$ excretion. Also, OPG had a significant positive correlation with bone formation markers (ALP and OC). This could be explained in view of steroid-induced direct inhibition of osteoblast differentiation ${ }^{(4)}$ with a resultant decrease of its products (OPG, OC and ALP)

The present study revealed a significant reduction of markers of bone formation (OC and ALP) and a significant increase of 24 hours urinary $\mathrm{Ca}$ (the studied marker of bone resorption) in all studied groups of patients than in controls. Few studies have been conducted for the evaluation of the 
magnitude and mechanism of osteopenia in children with NS, but results were conflicting. Similar to our findings are those of one study ${ }^{(16)}$ which reported enhancement of bone resorptive markers and suppression of bone formation markers in NS. However, in another recent study ${ }^{(17)}$ conducted on Egyptian children with NS, osteopenia was associated with increased bone resorptive markers while bone formation markers were normal. On the other hand, other investigators ${ }^{(18)}$ reported reduced markers of bone formation (ALP and OC) in NS. These discrepancies may be attributed to variations in the number and age of the studied patients, duration of illness, steroid dose and the methodology used to assess the laboratory markers of bone metabolism.

The significant increase of markers of bone formation and decrease of markers of bone resorption in our newly diagnosed patients with NS, prior to GC therapy, as compared to healthy controls may point to the significant role of the renal disease itself in the abnormality of bone metabolis $\mathrm{m}$ in NS. Gulati and associates ${ }^{(1)}$ mentioned that biochemical derangements caused by the renal disease itself is one of the important leading causes of metabolic bone disease in NS, Other investigators reported that abnormalities of bone metabolism in NS occurred irrespective to steroid therapy as $\mathrm{GC}$ is not the only factor responsible for osteopenia. Other factors may contribute as nutritional deficiency, hypoproteinemia, immobilization ${ }^{(19)}$ and proinflammatory cytokines excessively produced in active inflammation which triggers excessive osteoclastic activity ${ }^{(5)}$.

An important factor contributing to derangement in bone metabolism in NS is the steroid therapy ${ }^{(1)}$. In our study, patients who were FR had received a significantly higher cumulative steroid dose than those who were IFR. The former group had significantly lower parameters of bone formation and significantly higher 24 hours urinary $\mathrm{Ca}$ than the latter group. Osteoporosis is a well known serious side effect of long-term treatment with GC. However its precise mechanism is unclear. Pharmacologic doses of $\mathrm{GC}$ result in an increase of urinary $\mathrm{Ca}$ excretion due to stimulation of bone resorption directly by enhancing osteoclast activity and indirectly via increasing the production of PTH. Also, GC directly inhibit bone formation by decreasing osteoblast differentiation ${ }^{(3)}$. The latter assumption could explain the significantly lower OPG, OC and ALP, which are osteoblast products, in steroidtreated patients with NS than healthy controls

A short-course of GC therapy (for one month) received by our newly diagnosed patients with NS for the first time resulted in a significant reduction of $O P G$ and markers of bone formation (OC and ALP) and a significant increase of 24 hours urinary $\mathrm{Ca}$. In contrast, the one month GC therapy did not seem to significantly affect the serum levels of any of PTH, Ca and P. This came in accordance with the results of a previous study ${ }^{(2)}$ which reported that short-term GC administration to adult patients with different renal diseases had significantly suppressed serum OPG with concomitant enhancement of bone resorptive markers and suppression of bone formation markers. In contrast, there were 
negligible effects on PTH levels. They claimed that bone resorption after a short course of GC therapy had resulted from an inhibition of OPG rather than increment of PTH production.

In our series, patients with a history of frequent relapses and who were receiving high cumulative steroid dose had significantly higher PTH than those who were IFR and with low cumulative steroid dose. The former group had significantly higher serum PTH than healthy controls, while the latter group and healthy controls had comparable results of serum PTH. These findings denoted that prolonged course and high dose of $\mathrm{GC}$ therapy resulted in significant increase of serum PTH levels. In contrast, short course and low dose of GC administration did not seem to significantly affect serum PTH levels. Contradictory to our results, other investigators ${ }^{(20,21)}$ reported normal serum PTH levels in children with steroid-dependent and frequently-relapsing NS. These discrepancies may be attributed to variations in the duration of illness and cumulative steroid dose. Further studies on a large scale are warranted to measure serum PTH expression in NS in relation to steroid therapy and frequency of relapses. In our study, PTH showed a significant negative correlation with OPG. In 2000, Roux and Orcel $^{(5)}$ demonstrated that PTH

\section{REFERENCES}

1. Gulati, S.; Godbole, M.; Singh, U.; Gulati, K. and Strivastava, A. (2003): Are children with idiopathic nephrotic syndrome at risk for metabolic bone disease? Am. J. Kidney Dis ; 41 (6): $1163-9$

2. Sasaki, N.; Kusano, E.; Ando, Y.; Yano, K.; Tsuda, E. and Asano, Y. (2001): Glucocorticoid decreases circulating osteoprotegerin (OPG): upregulates RANKL and downregulates OPG expression in osteoblast / stromal cells which confirms the results of our study.

Several lines of evidence indicate that OPG / RANKL / RANK system plays a critical role in the development and function of the immune system ${ }^{(14,22,23)}$. Thus, OPG / RANKL / RANK system may mediate important and complex links between the skeletal, and immune systems ${ }^{(22)}$. RANKL blockade (using OPG, RANK fusion proteins or RANKL antibodies) has prevented bone loss caused by osteoporosis and chronic inflammatory disorders ${ }^{(24)}$ OPG is currently under investigation for osteoporosis treatment ${ }^{(25,26)}$

In conclusion, osteoporosis in NS could be attributed to both enhancement of bone resorption and suppression of bone formation. Low OPG expression, which could be attributed to both renal disease itself and steroid therapy, may be an important factor contributing to bone resorption in NS. Thus, OPG administration may be considered as a new hopeful therapeutic modality for osteoporosis in NS, especially in patients who are frequent relapsers and with high cumulative steroid dose. Further studies regarding the protective effects of OPG administration against bone loss in NS are warranted.

possible mechanism for glucocoticoid-induced osteoporosis. Nephrol. Dial. Transplant.; 16 (3): 479-82.

3. Sprague, S. (2000): Mechanism of transplantation-associated bone loss. Pediatr. Nephrol.; 14 (7): 650-3

4. Freundlich, M.; Alonzo, E.; Bellorin-Font, E. and Weisinger, J. (2005): Increased 
osteoblastic activity and expression of receptor activator of NF-Kappa B ligand in nonuremic nephrotic syndrome. J. Am. Soc. Nephrol:; 16 (7): $2198-204$

5. Roux, S. and Orcel, P. (2000): Bone loss. Factors that regulate osteoclast differentiation. An update. Arthritis Res. ; 2 (6): 451-6.

6. Saidenberg Kermanach, N.; Bessis, N.; Cohensolal, M.; De Vernejoul, $M$, and Boissier, M. (2002): Osteoprotegerin and inflammation. Eur. Cytokine Netw.; 13 (2): 144 53.

7. Kong, Y.; Feige, U.; Sardosi, I.; Bolon, B.; Tafuri, A.; Morony, S.; et al. (1999): Activated $T$ cells regulate bone loss and joint destruction in adjuvant arthritis through osteoprotegerin ligand. Nature; 402 (6759): 304-9.

8. Ritchlin, C.; Haas-Smith, S.; Li, P.; Hicks, D. and Schwarz, E. (2003): Mechanisms of TNFalpha and RANKL-mediated osteoclastogenesis and bone resorption in psoriatic arthritis. J. Clin. Invest.; $111(6): 821-31$

9. International Study of Kidney Disease in Children (1978): Nephrotic syndrome in children. Prediction of histopathology from clinical and laboratory characteristics at time of diagnosis. Kidney Int.; 13: 159-65.

10. Barratt, M. and Clark, G. (1999): Steroidresponsive nephrotic syndrome. In: Barrat, $\mathbf{M}$; Avner, E.; Harmer, W. editors. Pediatric Nephrology, $4^{\text {th }}$ ed. Baltimore: Williams and Wilkens; p. 731.

11. Schmidt-Gayk, H.; Spanuth, E.; Kotting, J.; Bartl, R.; Felsenberg, D. and Pfeilschifter, J. (2004): Performance evaluation of automated assays for (beta)-CrossLaps, N-MID-Osteocalcin and intact parathyroid hormone (BIOROSE Multicenter Study), Clin. Chem. Lab. Med., 42 (1): 90-5.

12. Garnero, P.; Grimaux, M.; Seguin, P. and Delmas, P. (1994): Characterization of immunoreactive forms of human osteocalcin generated in vivo and in vitro. J. Bone Miner Res.; 9 (2): 255-64

13. Feuerherm, A.; Borset, M.; Seidel, C.; Sundan, A.; Leistad, L.; Ostensen, M.; et al. (2001): Elevated levels of osteoprotegerin (OPG) and hepatocyte growth factor (HGF) in rheumatoid arthritis. Scand. J. Rheumatol.; 30 (4): 229-34.

14. Saidenberg-Kermanac'h, N.; Cohensolal, M.; Bessis, N.; De Vernejoul, M. and Boissier, $M$. (2004): Role for osteoprotegerin in rheumatoid inflammation. Joint Bone Spine; 71 (1): 9-13.

15. Fahrleitner, A.; Prenner, G.; Leb, G.;
Tscheliessnigg, K.; Piswanger-Solkner, C.; Obermayer-Pietsch, B.; et al. (2003): Serum osteoprotegerin is a major determinant of bone density development and prevalent vertebral fracture status following cardiac transplantation. Bone; 32 (1): 96-106.

16. Biyikli, N.; Emre, S.; Sirin, A. and Bilge, I. (2004): Biochemical bone markers in nephrotic children. Pediatr. Nephrol,; 19 (8): 869-73.

17. Abu Al-Hassan, S.; El-Ziny, M.; Sarahan, A.; Bakr, A.; Hammad, A.; Chalaby, N.; et al. (2003): Bone mineral density and bone turnover markers in children with primary nephrotic syndrome. Geget; 3 (2): 11-6.

18. Rubin, M. and Bilezikian, J. (2002): The role of parathyroid hormone in the pathogenesis of glucocorticoid-induced osteoporosis: a reexamination of the evidence. J. Clin. Endocrinol. Metab.; 87 (9): 4033-41

19. Kerstetter, J.; O'Brien, $\mathbf{K}$ and Insogna, $\mathbf{K}$. (2003): Low protein intake: the impact on calcium and bone homeostasis in humans. J. Nutr,; 133 (3): 855S-61S.

20. Mittal, S.; Dash, S.; Tiwari, S.; Agarwal, S.; Saxena, S. and Fishbane, S. (1999): Bone histology in patients with nephrotic syndrome and normal renal function. Kid. Int; 55 (5) 1912-9.

21. Soliman, G.; Fouda, M.; Sayed, S. and Malek, I. (2004): Parathyroid hormone, osteocalcin, and bone mineral density in children with steroiddependent and frequently-relapsing nephrotic syndrome Geget; $4: 71-8$.

22. Osdoby, C. (2004): Regulation of vascular calcification by osteoclast regulatory factors RANKL and osteoprotegerin. Circ. Res.; 95 (11): 1046-57.

23. Hofbauer, L.; Heufelder, A. and Erben, R. (2001): Osteoprotegrin, RANK and RANK ligand: the good, the bad, and the ugly in rheumatoid arthritis. J. Rheumatol; $28: 685-7$

24. Hofbauer, L. and Schoppet, M. (2004): Clinical implications of the osteoprotegerin/ RANKL/RANK system for bone and vascular diseases. JAMA; 292 (4): 490-5.

25. Coetzee, M. and Kruger, M. (2004): Osteoprotegerin receptor activator of nuclear factor-Kappa B ligand ratio: a new approach to ostcoporosis treatment? South Med. J.; 97 (5): 506-11.

26. Sattler, A.; Schoppet, M.; Schacfer, J. and Hofbauer, L. (2004): Novel aspects on RANK ligand and osteoprotegerin in osteoporosis and vascular disease. Calcif. Tissue Int.; 74 (1): 103. 6. 